\title{
Notes on the Political Economy of State Intervention in Nigeria
}

\section{Tom Forrest}

This note is concerned with state intervention in Nigeria, where both state and local private capitalist enterprise are weak, but where there exist pressures for greater autonomy from foreign capital and influence. It is argued that recent state intervention has not succeeded in creating the conditions for a productive pattern of capitalist development. It is further suggested that prominent features of the Nigerian State and public policy are best analysed if the State is understood to be the site of class interaction. This approach has the advantage of relating state institutions, policies and personnel to civil society. The logic of state intervention can then be examined, not simply in instrumental, universal terms like growth, welfare and efficiency, or in terms of the interests of a single class, but as the resolution of certain economic and social forces.

\section{Conceptual limitations}

Before pursuing this argument, however, it is worthwhile setting out some of the limitations of existing economic approaches to the State. These have been influential in determining conceptions of development and the framework for policy and research in Nigeria and elsewhere. They are also, in a wider sense, part of the fabric of ideas transferred from western intellectual centres to Nigeria which would need to be considered in any detailed account of Nigeria's political economy. The Anglo-Saxon mainstream economics tradition which has dominated economic thinking in Nigeria does not provide the basis for an adequate interpretation of the role of the State. The normative roots of this tradition are located in a specifically European experience of the relation between the State and civil society and the rise of industrial capitalism. It is not obvious that judgments about the State which incorporate these values will lead to an understanding of social and economic forces in different historical circumstances. Simply to transfer the term 'mixed economy' is to introduce a number of assumptions about public and private domains which can obscure the nature of the State and the relations between foreign, private and public enterprise. Economic analysis has detached the State from its socio-economic context and given it an historical, instrumental role which is often simply taken for granted. This procedure is naturally attractive to those economists who see their discipline as nothing if not a policy science, and it becomes irresistible where an ideology exists which sees the State as the main agent of development. The result is that the logic of state intervention comes to be presented in terms of universal ends like growth, welfare and efficiency. Important qualitative relations between surplus generation, investment and growth are neglected. Conflicts of interest are not recognised. This kind of abstraction from reality is familiar in the planning literature where technocratic models assume the existence of a powerful central agency while ignoring the actual process of planning and the economic mechanisms that do exist. This neglect of the State in society not only impoverishes understanding and prescription, it also precludes the development of a comparative political economy.

\section{Efforts to develop productive capitalism in Nigeria}

The Nigerian State has generally supported foreign capital. The colonial State encouraged and regulated the transfer of crops, capital and labour from the peasant primary sector. On this basis, the State supported foreign capital accumulation in commerce, finance and metropolitan industry. Nigeria's sterling balances, state revenues and level of economic activity were all tied to the fortunes of export commodities. When monopoly or war threatened the orderly export of produce or supply of imports, the State intervened. The peasant surplus also financed the provision of public utilities and infrastructure which were a necessary part of the colonial economic system. The extractive role of the marketing boards, apart from its long-term disincentive effect on agricultural output, also impeded Nigerian capital formation by transferring funds to the colonial State. As Sir Percival Griffiths wrote in 1955, "it means that the Development Board which operates the Marketing Board surplus funds in Nigeria is in fact the only potential African investor .... the economic pattern is thereby being set along the lines of state socialism .... when ministers and officials talk of African capital participation in new ventures they almost invariably mean participation 
by the Development Board. The foreign investor thus faces a dilemma. Either he must provide all the capital and so be vulnerable to nationalist attack, or else he must enter into partnership with a quasi-government corporation, and this latter possibility will be unattractive to most capitalists." (Griffiths, 1955). Griffiths went on to show how control over the network of credit enabled metropolitan capital to monopolise largescale commercial activity. However, fundamental shifts of power within the State after 1952 increased competition among industrial exporters, and nationalist demands for a share in the distributive trade weakened the position of British commercial capital.

With the approach of independence, the State provided finance, protection and tax incentives in the early stages of industrialisation. Considerations of market strategy, various types of state subsidy and tariff escalation due to balance of payments difficulties in the early 1960 s, all encouraged the expansion of foreign capital from its commercial base into manufacture and prompted the flow of new investment from abroad. Although there was a withdrawal of foreign capital from commerce during this period, it should not be exaggerated. Foreign capital still dominates important sections of the import and wholesale trade where distributive monopolies are the norm. Thus import substitution", which involved the establishment of the capitalist mode and the internationalisation of production and consumption was not part of a planned, coherent strategy of industrialisation. Nigerian business was effectively restricted to comercial and service activities, to small-scale capitalism and to non-capitalist formations. This pattern of accumulation and productive relations has persisted despite new initiatives by the State. The commercial bourgeoisie plays what is essentially an intermediary role between the consumer and the State on the one hand, and foreign capital and the international market on the other. Its interests are allied to those of foreign capital.

'Nigerianisation not nationalisation' was the theme of a political class which sought to increase its wealth through commerce, urban poverty and links with foreign capital. It dispensed patronage to indigenous businessmen and created employment for nationals by the expansion of the public service and the replacement of foreign personnel. Foreign capital was secure and it responded to this bourgeois nationalism by further investment and by the employment of nationals as Board members, managers and as middlemen who had access to the state machinery.
An important state institution in this period was the statutory corporation in the form of marketing boards and regional development corporations. These state institutions were the means whereby enlarged state revenues were mobilised and distributed. Yet in the absence of an effective class basis the State proved incapable of regulating and administering these institutions and the intense regional pressures to which they were subject. The State lacked autonomy, and tidy distinctions between the private and public interest had no place where politicians and businessmen were one and the same. Both state intervention and laissez-faire were exercises of political power by interests which aspired to control the State and use it for their own ends. In the analyses of economists, the marketing boards underwent an interesting evolution from being instruments of price and income stabilisation to being a means of taxation, to become finally an instrument for mobilising development funds. By the 1960s the reality had become more complex. As Wrigley writes, statutory marketing boards became a "convoluted collaboration of government, party public corporation, and private business" (Wrigley, 1974). The regional loans boards as documented by Schatz fared little better (Schatz, 1970). In terms of the prevailing development strategy these bodies were to promote economic development through loans to indigenous private enterprise. They were not successful in promoting a productive bourgeoisie. The alternative strategy of directly productive state enterprise was not considered and the evidence appeared to be against it. Teriba, in his study of the Western Nigerian Development Corporation, concluded by stressing the superiority of an industrial development strategy relying on minority investments in private industry over that relying on exclusive investment and management by public development institutions (Teriba, 1966). By 1966 the pattern of investment in manufacturing was 10 per cent private Nigerian, 20 per cent State and 70 per cent foreign.

Military rule, a more powerful bureaucracy, oil surpluses, and the bitter experiences of civil war, provided the context for efforts to restrict the sphere of foreign capital and secure a more self-reliant pattern of development than that which characterised the First Republic. First, the Nigerian Enterprises Promotions Decree (NEPD) of 1972 (revised in 1977) attempted to strengthen national capital. Second, under the 1970-74 Second National Development Plan public corporations proliferated, and efforts were made to extend the operations of state enterprises into directly productive activities. Before looking at these 
measures in more detail, it will be useful to sketch some of the consequences of the large increase in oil revenue which coincided with them.

Oil revenues have underlined certain structural weaknesses in the open economy. Easy access to consumer goods, especially durables, and intermediate and capital goods has led to a commercial boom and intensified international competition for the Nigerian market. In cases where it has proved more profitable to import, this has positively discouraged local manufacturing. The narrow industrial base has not been diversified much beyond light consumer goods, assembly and processing. Engineering industry is virtually nonexistent. Domestic resources have been used in ways which do not promote self-sufficiency. For example, professional manpower is directed into the highly profitable commercial and service sectors, or into the foreign controlled sector which leads wage and salary movements. Food prices in urban areas rose sharply following the monetisation of oil revenues, and the food import bill rose to $\mathrm{N} 440 \mathrm{~m}$ in $1976 . .^{1}$ The State has responded with measures to increase food production including the organisation of production and marketing for root crops and grains, more favourable producer prices, subsidised inputs, and large-scale irrigation and mechanisation schemes.

A further consequence of dependence on oil revenues is the rapid turn round in the balance of payments from a $\mathrm{N} 3,100 \mathrm{~m}$ surplus in 1974 to a small deficit in 1976.

The N30,000m Third National Development Plan was based on the assumption of surpluses to 1980. An important element here is the large deficit on invisisible account (N1,400m in 1976) which reflects not only the flow of profits on foreign investment but also important services associated with the import trade and reliance on foreign technology, management and consultancy in both oil and non-oil sectors. Finally, the existence of a centralised oil surplus (oil revenues account for about $\mathbf{8 0}$ per cent of current federal revenues) has increased the share of state expenditure. In 1974-75 federal government expenditure accounted for 37 per cent of GDP.

This does not include statutory payments from the centre to the states, which, following changes in the federal revenue allocation formula, have become a more important element in states' revenues The State thus forms a large part of the

$1 \mathrm{~N} 1=50: 83$. Since the adoption of an administered exchange rate policy in April 1974, the Naira has appreciated in terms of sterling by 28 per cent.
Nigerian market, and state control over the distribution of the surplus has increased.

The first phase of the Nigerian Enterprises Promotions Decree required exclusive Nigerian ownership of categories of retail trade, service and small-scale enterprises, many of which were owned by Lebanese. No significant new entrepreneurial opportunities were opened up by this transfer, nor was the competitiveness of this lowtechnology sector with the state-protected, foreign-controlled sector increased. More signficant from a developmental perspective was the further requirement that enterprises with capital in excess of $\mathrm{N} 400,000$ or a turnover of $\mathrm{N} 1 \mathrm{~m}$ secure at least 40 per cent local participation. This was achieved through public and private issue of equity capital to managerial, bureaucratic, and professional strata. The measure had the simultaneous effect of enlarging the capital base of foreign controlled enterprises and making the capitalist mode acceptable to groups whose consumption-and now income-depend directly on it. It marked a large step in the accumulation and concentration of wealth by the bourgeoisie. Together with land and urban property, these assets will set up a skewed distribution of income in the future.

Under the second phase of the decree there will be an extension of Nigerian ownership by equity participation These schedules cover full, majority and minority Nigerian ownership. How far do these schedules follow the pattern of higher technology enterprises being associated with majority foreign ownership? This pattern is disturbed on two counts. First, there is the presence of large commercial enterprises like UAC, Holts, PZ, SCOA and Leventis which are now required to extend Nigerian participation from 40 to 60 per cent. These descendants of colonial mercantile capital are exempt from Schedule 1 of the decree which reserves the wholesaling of locally manufactured goods such as textiles for Nigerians. Second, a number of older established industries like tobacco, textiles, and pharmaceuticals remain with a majority foreign interest.

On the whole the decree has accommodated the interests of foreign capital. It will strengthen the transnational component of the bourgeoisie, though effective control will not pass to this managerial group. Given the weakness of national capital, the State is not in a very strong position to legislate measures to extend local ownership or control foreign technology compared with, for example, India or Mexico. To sustain the rather uncertain flow of foreign investment, the government has given repeated assurances that the 
indigenisation measures are not aimed at nationalisation.

Where the State has participated with foreign capital in joint ventures (oil, vehicle assembly, construction, fertilisers, cement, agro-industry), it is less indicative of a strong productive state capitalism than the performance of a support role for foreign capital. Murray aptly notes that state interests "represented in peripheral manufacturing capital linked with locally operating metropolitan capital, via joint ventures for example, take a ... share of the surplus value which represents a rent on nationality, political connections and privileged access to some types of economic information" (Murray, 1972). The main effort of the Nigerian National Oil Corporation has been successfully directed at obtaining a larger share of the oil revenues. Transfer of technology has proceeded slowly and the corporation has recently become involved in drilling and exploration activity. The activities of the corporation are thus essentially commercial and administrative. They do not yet displace the functions of the multinational oil firms or their specialist foreign sub-contractors to any significant extent. The Nigerian Mining Corporation has taken a minority interest in foreign tin companies and plans to become directly involved. in mining operations.

Below the federal level the corporate strength of state institutions is variable. On the one hand, the New Nigeria Development Company has an extensive investment portfolio, often in partnership with foreign capital. At the other extreme, and on a smaller scale, the Kano State Investment Corporation under the Gowon regime was operated like a private company by state officials. Many of its unprofitable investments were prompted by aliens who needed local investment to meet the requirements of the NEPD. The corporation also acted as a commission agent for foreign parties who were trying to buy crude oil from Nigeria and for Nigerians who imported cement and milk.

It is in the financial sector that state power and economic control is most likely to be exercised in an attempt to direct resources towards a more productive pattern of investment. The State has taken a majority interest in the commercial banks and a larger role is envisaged in the expansion and consolidation of the existing state banks (the Nigerian Industrial Development Bank and the Nigerian Banks for Commerce and Industry) to provide credit for industrial ventures. Recent legislation has directed the small, newly arrived group of merchant banks to shift their assets from highly profitable trade-related assets to longer-term lending. It seems unlkely, however, that these moves to alter investment patterns by changing the financial structure will be successful without changes at the level of economic organisation.

\section{Commercial relations as obstacles to production}

Why have the many state initiatives aimed at promoting rapid development of capitalist production not yielded better results? The underdevelopment of manufacturing received much attention in the 1975-80 Third National Development Plan which states that despite a high rate of GDP growth of 12 per cent between 1962 and 1972,

"the share of manufacturing and craft increased by only 2.15 per cent rising from 5.64 per cent of GDP in 1962 to 7.79 per cent in 1972. The current 8 per cent share of manufacturing in GDP compares quite unfavourably with the 15 per cent to 20 per cent share attained in many countries at a similar stage of economic development. A recent study of the experiences of about 90 countries of varying sizes and degrees of development suggests that Nigeria today should have a manufacturing sector representing about 16 per cent of the GDP. While part of the difference between the actual and expected share of the sector in the GDP can be explained by the unusual importance of the oil sector, the Nigerian manufacturing sector is nevertheless underdeveloped relative to the size and the general level of development of the whole economy."

\section{(Central Planning Office, 1975 : 147).}

One widely accepted reason for the reluctance of Nigerian entrepreneurs or foreign firms to undertake production is the absence of adequate infrastructure. This similarly deters state corporations which are established to undertake profit-orientated ventures. But many infrastructural projects are themselves types of state capitalism which involve productive activity. It remains to explain the difficulties in getting projects off the ground.

Much has been said about the shortage of managerial and technical manpower. At the same time the State has attempted to exercise control over the employment of foreign personnel to ensure Nigerianisation. It is difficult to disentangle myth from reality here. Foreign companies have little difficulty in securing the services of qualified Nigerians, although they may not retain their services for long in an intensely competitive market. It should be noted however, that it may be in the interest of foreign companies to pro- 
mote the idea of manpower shortage in order to reserve key management positions for aliens and block the effective transfer of technology. Thus the build-up of local technological capacity can be delayed. The result is frustration, the underutilisation of qualified personnel, a fragmentation of expertise, and continued dependence on foreign personnel.

The slow growth of productive capitalist ventures despite the availability of competent personnel and abundant investment funds may be more adequately explained by the very profitable opportunities for commerce which remain open. As the 1975-80 Plan noted, "in a country growing as rapidly as Nigeria, trading activities normally represent the quickest means of increasing income, whereas manufacturing projects usually have a long gestation period" (Central Planning Office, 1975 : 152). Here the role of certain groups represented in the State must be considered. As a market, the state itself absorbs large quantities of imports. Decisions on expenditure, the award of contracts and the granting of various dispensations in the course of effecting these transactions all involve officials in a national-foreign commercial network. It has been noted that most Nigerian businessmen perform an intermediary or middleman role. Many State-foreign transactions are mediated by middlemen, just as many exchanges between final consumers and foreign manufacturers are effected by the local commercial bourgeoisie. To reduce imports is to reduce the business of this class. In practice, as oil revenues have allowed for the expansion of expenditure, the class of commercial middlemen has itself grown. The nexus between state official, local middleman and foreign salesman is intimate and reciprocal and characterised by the interchange of roles among the indigenous personnel of business and state officials. There is reason to expect that these three sets of actors will try to preserve the relations which allow for profitable transactions.

A corollary of the fact that commerce offers more attractive openings for profit than does investment in production is that individuals with skills, experience and the drive to accumulate money are naturally drawn into an intermediary role. They are encouraged to take this route by the growing number of foreign firms that seek to penetrate the Nigerian market or secure a larger share of that market. Those nationals most likely to respond to overtures from foreign firms are those with education and international experience. They are also the Nigerians most suited to undertake the organisation of capitalist production.

Commerce does not inevitably evolve into productive activity and may positively discourage it. Contrary to the expectations of many, the Nigerian middleman who has accumulated significant funds does not invest in production. He or she is much more likely to extend the commercial operation laterally so as to encompass the distribution of more commodities and to extend it 'upstream' to absorb the marketing and distribution functions which are closer to the foreign manufacturing operation itself. For instance, an importer may add pre-frabricated housing units to his import list of building materials. He may extend into shipping in order to transport the goods which hitherto he purchased c.i.f. This pattern of commercial extension may occur in partnership with foreign firms such that the links between Nigeria's commercial bourgeoisie and the industrial bourgeoisie multiply and are intensified over time. Mergers and an interlocking pattern of commercial interests enable us to identify a Nigerian component of the international bourgeoisie.

There is little documentation of this pattern of development. Case studies of the growth of private commercial firms in Nigeria have yet to be made. They might test the "incompatibility hypothesis' presented here which explains the underdevelopment of production by the profitability of international commerce and suggests that commerce rules out local capitalist production. An assesment of the evolution of Nigerian commerce would have to take into account the context provided by an inadequate infrastructure, the involvement of the state in commerce, and the preemption of certain productive opportunities by foreign capital.

In conclusion, local manufacturing and the development of intermediate and capital goods industries have long been a 'development objective' of high priority for planners. Yet various attempts by the State to promote structural changes in the economy and take the initiative from foreign capital have not been very successful. The strength of commercial relations and reliance on foreign management and technology supports the dominance of the commericial and managerial fractions of the bourgeoisie. Both the policies and the capacity to evolve a more productive national base for capital accumulation are weakened by these social relations. 


\section{References}

Central Planning Office, 1975, The Third National Development Plan, 1975-80, Vol. 1, Ministry of Economic Development, Lagos.

Griffiths, Sir Percival, 1955, 'Investing in West Africa', Financial Times, June 7.

Murray, Robin, 1972, 'Underdevelopment, International Firms and the International Division of Labour', in Towards a New World Economy, Rotterdam University Press, Rotterdam.
Schatz, S. P., 1970, Economics, Politics and Administration in Government Lending, OUP, Oxford.

Teriba, O., 1966, 'Development strategy, investment decision and expenditure patterns of a public development institution : the case of the Western Nigerian Development Corporation, 1949-1962', Nigerian Journal of Economic and Social Studies.

Wrigley, C. C., 1974, 'The development of state capitalism in late colonial and post-colonial Nigeria', ASAUK, Liverpool 